Original research article

\title{
Resilience, occupational satisfaction, burnout and compassion fatigue in Turkish intensive care nurses
}

\author{
Elvan Emine Ata ${ }^{1 *}$, Emel Bahadır Yılmaz ${ }^{2}$, Nurten Gülsüm Bayrak ${ }^{3}$ \\ ${ }^{1}$ University of Health Sciences, Hamidiye Faculty of Nursing, İstanbul, Turkey \\ ${ }^{2}$ Giresun University, Faculty of Health Sciences, Midwifery Department, Giresun, Turkey \\ ${ }^{3}$ Giresun University, Prof. Dr. A. İlhan Özdemir Training and Research Hospital, Giresun, Turkey
}

\begin{abstract}
Nurses' resilience and occupational satisfaction are important factors for preventing burnout, compassion fatigue and turnover of intensive care unit (ICU) nurses. This study determined the relationship between resilience and occupational satisfaction, burnout and compassion fatigue in Turkish intensive care unit nurses. This descriptive, correlational, cross-sectional study was conducted with 79 ICU nurses. Data were collected using a personal information form, the Life Quality Scale for Workers, and the Resilience Scale for Adults. The mean scores for the ProQOL subscale scores were examined; occupational satisfaction $24.64 \pm 8.45$, burnout $19.17 \pm 6.24$ and compassion fatigue $13.45 \pm 5.69$. The resilience scale total score was $128.67 \pm 14.84$. There is a positive moderate relation between resilience and occupational satisfaction, and a negative moderate relation between resilience and burnout. Improving the resilience of ICU nurses can be a useful strategy for decreasing their occupational satisfaction and burnout. Nurse managers may use the results of this study for designing programs to facilitate the development of resilience in all nurses working in intensive care units.
\end{abstract}

Keywords: Burnout; Compassion fatigue; Nursing; Occupational satisfaction; Resilience

\section{Introduction}

Nurses working in intensive care units - where bedside care services are provided and where ongoing care and treatment are maintained - face psychosocial stressors resulting from both the environment they work in and the intense working conditions of the clinical area (Amin et al., 2015). Many factors cause nurses to feel stressed, such as time pressure, workload, having many responsibilities, caring for dying patients, and ethical and emotional problems (Baek et al., 2019; Ingebretsen and Sagbakken, 2016; Lim et al., 2011; McCann et al., 2013). The intense stress experienced can negatively impact nurses professionally and mentally and may lead to a condition called compassion fatigue (Craigie et al., 2016; Figley, 1995).

Compassion fatigue is a concept that is described in different ways in the literature and expressed as being the price paid for nursing care. It is explained as being the emotional impact of the trauma caused by giving care and is experienced by individuals who give care to individuals exposed to trauma (Figley, 2002; Şirin and Yurttaş, 2015). Compassion fatigue is defined as physical, emotional, social, and mental exhaustion that overwhelms an individual and causes an overall reduction in the desire, ability, and energy that the caregiver has to empathize with and care for others (Şirin and Yurttaş, 2015).
Compassion fatigue occurs as a natural consequence of working with individuals who have experienced trauma or stressful events (Meadors and Lamson, 2008). In some studies, it is emphasized that $50 \%$ of those who help traumatized individuals are at risk of compassion fatigue (Injeyan et al., 2011; Wee and Myers, 2002). Many studies emphasize that compassion fatigue is a widespread problem; notably among nurses working in forensic units, clinical areas such as oncology, pediatrics, intensive care, and emergency departments, and hospices (Beck, 2011; Hooper et al., 2010; Ingebretsen and Sagbakken, 2016; Najjar et al., 2009; Wentzel and Bry-Siewicz, 2014; Yoder, 2010). It is also stated that nurses living with this condition may become tired, overwhelmed, desperate, and hopeless about their own condition or life (McHolm, 2006).

On the other hand, the idea of compassion fatigue brings other concepts along with it. Burnout can also be seen alongside compassion fatigue in nurses who provide care to traumatized individuals (Figley, 2002). Burnout occurs because of environmental factors such as working conditions, workplace violence, long-term hospitalizations, excessive busyness, planning for unrealistic patient expectations, and management (Gentry et al., 2002; Zhang et al., 2018). In addition, giving care to an individual who needs help does not always lead to compassion fatigue and causes the caregiver to experience

\footnotetext{
* Corresponding author: Elvan Emine Ata, University of Health Sciences, Hamidiye Faculty of Nursing, Selimiye Mah. Tibbiye Cad. No: 38, 34668 Üsküdar, İstanbul, Turkey; e-mail: elvanhenden@gmail.com http://doi.org/10.32725/kont.2020.028 
positive feelings. The positive psychological effect of providing care to someone else is expressed by the term "occupational satisfaction" (Figley, 2002). The term "occupational satisfaction" refers to the positive emotions felt by a nurse when success is achieved in the caregiving process and when an empathic and ethic relationship with patients is established (Slatten et al., 2011). Occupational satisfaction ensures that nurses feel better emotionally, can establish a connection, and have meaningful interaction with the patients they care for and use ethical codes when they are providing care to patients (Young et al., 2011).

To increase the quality of patient care and the occupational satisfaction levels of employees, the compassion fatigue of nurses must be addressed. This is because compassion fatigue is a condition that desensitizes nurses and makes it harder for them to commit to their job, reducing the quality of the care provided. In addition, it becomes increasingly difficult for nurses who are beginning to experience burnout due to compassion fatigue to commit to the work they do; their performance drops, and absenteeism increases (Stamm, 2002). It is becoming increasingly important to protect nurses from compassion fatigue to prevent this situation.

Compassion fatigue prevention strategies are multifaceted. The goal of these strategies is to maintain the physical, mental, emotional, social, and mental well-being of the nurses (Potter et al., 2013). It is known that nurses working in intensive care units are exposed to intense stress in their working environments, experience compassion fatigue because of this stress, feel professionally exhausted, and become desensitized, and the quality of the care they provide is reduced (Lim et al., 2011; McCann et al., 2013; Zhang et al., 2018). In this context, one of the most important qualities that enable nurses to recover quickly in the face of stressful events is resilience. Resilience is defined as the ability to recover quickly from disease, depression, changes, or bad situations, as being able to collect oneself, as being able to easily return to one's original state after being hurt and becoming stressed, and as elasticity (Earvolino-Ramirez, 2007). Resilience is the ability of a person to cope with and be successful in the face of many negative circumstances, such as obstacles and uncertainty (Luthans et al., 2006). The resilience of the nurse will contribute to fulfilling the tasks expected of themselves, maintaining their relationships healthily and being successful in their professional life. For this reason, it is even more important to protect and develop the resilience levels of nurses. This study aimed to determine the relationship between the resilience of Turkish nurses working in ICUs and their occupational satisfaction, burnout and compassion fatigue level.

\section{Materials and methods}

\section{Study design}

This descriptive, correlational, cross-sectional study was conducted in a Turkish state hospital intensive care unit.

\section{Settings and participants}

This study was carried out between April 1 and June 1, 2016, at a State Hospital Intensive Care unit in Turkey. In this period, 100 nurses worked in intensive care units of this hospital. The sample size was calculated with Raosoft (sample size calculator) using the following values: margin of error $=5 \%$, confidence level $=95 \%$, and response distribution $=50 \%$, and based on the calculations, 80 individuals were assigned to a group. All nurses working in the units were invited to participate in the study. Seventy-nine nurses who worked at intensive care units volunteered to participate. The participation rate in the study was $79 \%$. The inclusion criteria were working in the intensive care unit and volunteering to participate in the study. Nurses who were on leave at the time of this study and who were not assigned to another department were excluded.

\section{Data collection tools}

The data were collected using the personal information form, the Professional Quality of Life Scale (ProQOL), and the Resilience Scale for Adults (RSA).

\section{The personal information form}

The form was prepared by the researchers in line with the relevant literature. In addition to demographic information such as age, gender, marital status, and educational status, the form includes questions about how many years they have been working for, which intensive care unit they are working in, whether they are satisfied with working in intensive care, and whether it was their own wish to work in intensive care.

\section{The ProQOL}

The ProQOL consists of 30 items and three subscales developed by Stamm (2002). The Turkish validity and reliability study of the scale was conducted by Yeşil et al. (2010). The first subscale is occupational satisfaction (10 item), and a high score on this subscale indicates the level of satisfaction or contentment that one has as a helper. A maximum of 50 points can be obtained, and a score between 0 and 33 points indicates low, between 34 and 42 points moderate, and between 43 and 50 points high occupational satisfaction. Its alpha reliability value is 0.88 . The burnout subscale ( 10 item) is the second subscale. A maximum of 50 points can be obtained, and a score between 0 and 18 points indicates that the burnout is low, between 19 and 27 points moderate, and between 28 and 50 points high. Its alpha reliability value is 0.57 . The empathy fatigue/compassion fatigue subscale (10 item) is the third scale. The alpha reliability value was 0.84 . A maximum of 50 points can be obtained from this subscale, and a score between 0 and 8 indicates that empathy fatigue/compassion $\mathrm{fa}$ tigue is low, between 9 and 17 moderate, and between 18 and 50 points high. The assessment of the items in the scale was done over a six-step scale ranging from "never" (0) to "very often" (5). In this study, the Cronbach's alpha value of the total scale was 0.85 .

\section{The RSA}

The RSA was developed by Firborg et al. (2005), and its Turkish validity and reliability study was carried out by Basım and Çetin (2011). The RSA consists of 33 items and is evaluated with a five-point Likert scale. The lowest score that can be obtained is 33, and the highest score is 165 . If the resilience is supposed to increase as the scores increase, then the answer boxes should be evaluated as 12345 from left to right. The total Cronbach's alpha coefficient of the original scale is 0.86 , and it was determined as 0.78 in this study.

\section{Data collection}

The purpose of the study was explained to the nurses, and those who consented to volunteer participated in the study. The surveying tools were filled out by the researchers by interviewing the nurses face-to-face for 15-20 $\mathrm{min}$.

\section{Data analysis}

The data obtained from the study were uploaded to the SPSS 22 software package. To analyze the data, frequencies and per- 
centage distributions were used to examine the identifying characteristics of the nurses and mean and standard deviation to evaluate the scores the nurses obtained from the scales. The Pearson correlation analysis was used to determine the relationship between the scales.

\section{Ethics}

For this study, written permission was obtained from Giresun Prof. Dr. A. İlhan Özdemir State Hospital ethics committee (28. 12. 2015 dated and 5692-8510 numbered). Before collecting data, the participants were informed about the purpose of the research and consent was obtained from the participants who wanted to participate in the study. All participants gave informed consent for the research, and assurance their anonymity would be preserved. The principles of the Declaration of Helsinki were considered in all stages of the study.

\section{Results}

\section{General characteristics}

The average age of the nurses who participated in the study is $34.94 \pm 5.94$ years; $51.9 \%$ have undergraduate degrees, the average years of work is $13.37 \pm 6.71$, and they have been working in intensive care units for an average of $6.16 \pm 5.74$ years. Of the nurses, $69.6 \%$ stated that they had chosen to work in intensive care units, $89.9 \%$ said they would once again choose to work in intensive care units if they could choose again, and $73.4 \%$ were partly satisfied with the working conditions. It was determined that $15.2 \%$ of the nurses frequently experienced emotional strain when giving care to patients and that $12.7 \%$ always had difficulty communicating bad news to patients' relatives (Table 1 ).

Table 1. Some identifying characteristics of the nurses

\begin{tabular}{lc}
\hline Gender & \\
Female & $76(96.2)$ \\
Male & $3(3.8)$ \\
\hline Marital status & \\
Married & $60(75.9)$ \\
Single & $19(24.1)$ \\
\hline Educational status & \\
Medical vocational high school diploma & $3(3.8)$ \\
Associate degree & $29(36.7)$ \\
Bachelor's degree & $41(51.9)$ \\
Master's degree & $6(7.6)$ \\
\hline Unit worked in & \\
Neurology ICU & $12(15.2)$ \\
Coronary ICU & $7(8.9)$ \\
Surgery ICU & $8(10.1)$ \\
Internal medicine ICU & $8(10.1)$ \\
General ICU & $28(35.4)$ \\
Anesthesia and reanimation ICU & $11(13.9)$ \\
Cardiovascular surgery ICU & $3(3.8)$ \\
Emergency ICU & $2(2.5)$ \\
\hline Satisfaction with working conditions & \\
Satisfied & $15(19.0)$ \\
Unsatisfied & $6(7.6)$ \\
Partly satisfied & $58(73.4)$ \\
\hline Occupational satisfaction & \\
Satisfied & $16(20.3)$ \\
Unsatisfied & $9(11.4)$ \\
Partly satisfied & $54(68.4)$ \\
\hline
\end{tabular}

\begin{tabular}{lc}
\hline $\begin{array}{l}\text { The choice of working in intensive care } \\
\text { I chose it myself }\end{array}$ & $55(69.6)$ \\
I did not choose it myself & $24(30.4)$ \\
\hline $\begin{array}{l}\text { Choosing to work in intensive care again } \\
\text { I would choose it again }\end{array}$ & $71(89.9)$ \\
$\quad$ I wouldn't choose it again & $8(10.1)$ \\
\hline Experiencing emotional strain when giving care to oatients & \\
$\quad$ Never & $7(8.9)$ \\
Sometimes & $59(74.7)$ \\
Frequently & $12(15.2)$ \\
Always & $1(1.3)$ \\
\hline $\begin{array}{l}\text { Having difficulty communicating bad news to patients' } \\
\text { relatives }\end{array}$ \\
$\quad$ Never & \\
Sometimes & $11(14)$ \\
Frequently & $43(54.4)$ \\
Always & $15(19.0)$ \\
& $10(12.7)$ \\
\hline
\end{tabular}

\section{ProQOL and RSA scores}

When the average ProQOL subscale scores were examined, occupational satisfaction was found to be $24.64 \pm 8.45$, burnout $19.17 \pm 6.24$, and compassion fatigue $13.45 \pm 5.69$. The resilience scale average total score of the nurses is $128.67 \pm 14.84$ (Table 2).

\section{Corelations between resilience and occupational satisfaction, burnout, and compassion fatigue}

A positive moderately significant relationship was found between resilience and occupational satisfaction ( $r=0.383, p=$ 0.000 ), and a negative moderately significant relationship between resilience and burnout $(r=-0.424, p=0000)$. No significant relationship was established between resilience and compassion fatigue $(p>0.05)$. A negative moderately significant relationship was found between burnout and perception of the future, family cohesion, perception of self, social competence, and social resources $(p<0.05)$. A positive moderately significant relationship was found between occupational satisfaction and family cohesion, perception of self, social competence, and social resources $(p<0.05$; Table 3$)$.

\section{Discussion}

The ethical codes of the nursing profession enable nurses to provide more compassionate care. Patients want to receive sensitive and compassionate care from ICU nurses. The present study was carried out with ICU nurses. The occupational satisfaction scores of the nurses are low and their burnout and compassion fatigue scores are moderate. In a previous study, it was found that the nurses' occupational satisfaction score was $25.47 \pm 10.52$, burnout score $20.57 \pm 7.21$, and compassion fatigue score $23.97 \pm 13.68$ conducted (Coşkun et al., 2015). The compassion fatigue score of this study is higher than our study. The difference may be attributed to the fact that this study was conducted on nurses working in many different clinical areas. In another study assessing the working life quality of doctors and nurses, the occupational satisfaction score was $35.21 \pm 8.08$, the burnout score $25.72 \pm 5.80$, and the compassion fatigue score $14.63 \pm 7.23$ (Yeşil et al., 2010). The occupational satisfaction and burnout scores obtained from this study are much higher than our study. We believe that this may be caused by the fact that this study was not conducted only on nurses. In another study, it was found that the occupational satisfaction and burnout scores of nurses working in intensive 
Table 2. The distribution of the average ProQOL and RSA scores of the nurses

\begin{tabular}{lrrr} 
ProQOL & Min. & Max. & x sd \\
\hline Occupational satisfaction & 11.00 & 44.00 & $24.64 \pm 8.45$. \\
Burnout & 1.00 & 30.00 & $19.17 \pm 6.24$ \\
Compassion fatigue & 0.00 & 29.00 & $13.45 \pm 5.69$ \\
\hline RSA & & & $15.60 \pm 3.06$ \\
\hline Structural style & 7.00 & 20.00 & $15.88 \pm 2.90$ \\
Perception of the future & 8.00 & 20.00 & $23.36 \pm 3.72$ \\
Family cohesion & 12.00 & 30.00 & $23.87 \pm 3.68$ \\
Perception of self & 12.00 & 30.00 & $21.05 \pm 3.82$ \\
Social competence & 14.00 & 30.00 & $28.88 \pm 3.47$ \\
Social resources & 19.00 & 35.00 & $128.67 \pm 14.84$ \\
Total RSA & 92.00 & 162.00 & 12 \\
\hline
\end{tabular}

Table 3. The correlation between the RSA and ProQOL scores of the nurses

\begin{tabular}{|c|c|c|c|c|}
\hline & & \multicolumn{3}{|c|}{ ProQOL } \\
\hline RSA & & Occupational satisfaction & Burnout & Compassion fatigue \\
\hline \multirow{2}{*}{ Structural style } & $r$ & 0.097 & -0.134 & 0.082 \\
\hline & $p$ & 0.397 & 0.240 & 0.470 \\
\hline \multirow{2}{*}{ Perception of the future } & $r$ & 0.208 & -0.320 & -0.074 \\
\hline & $p$ & 0.066 & 0.004 & 0.516 \\
\hline \multirow{2}{*}{ Family cohesion } & $r$ & 0.403 & -0.400 & -0.205 \\
\hline & $p$ & 0.000 & 0.000 & 0.069 \\
\hline \multirow{2}{*}{ Perception of self } & $r$ & 0.230 & -0.358 & -0.212 \\
\hline & $p$ & 0.041 & 0.001 & 0.061 \\
\hline \multirow{2}{*}{ Social competence } & $r$ & 0.325 & -0.266 & -0.047 \\
\hline & $p$ & 0.003 & 0.018 & 0.681 \\
\hline \multirow{2}{*}{ Social resources } & $r$ & 0.342 & -0.325 & -0.106 \\
\hline & $p$ & 0.002 & 0.003 & 0.352 \\
\hline \multirow{2}{*}{ Total } & $r$ & 0.383 & -0.424 & -0.139 \\
\hline & $p$ & 0.000 & 0.000 & 0.223 \\
\hline
\end{tabular}

care were the lowest and that their compassion fatigue scores were low when compared with nurses working in other units (Başkale et al., 2016).

A study conducted in the United States evaluated the occupational satisfaction and compassion fatigue levels of nurses working in intensive care, and it found that their occupational satisfaction, compassion fatigue, and burnout scores were higher than those of our study (Sacco et al., 2015). In comparison with a study on nurses working at different clinical areas, it was found that the average occupational satisfaction (32.34 \pm 5.80$)$, compassion fatigue $(21.06 \pm 4.18)$, and burnout $(21.13 \pm 4.08)$ scores of nurses working in intensive care units were higher than those in our study conducted (Shen et al., 2015). Similarly, occupational satisfaction, burnout and compassion fatigue scores are higher in our study compared with the one of the study which determined the relationship between the resilience and working life quality of Australian nurses (Hegney et al., 2015), another study that compared the resilience and working life quality of nurses giving care to mentally challenged individuals in the community and in an institution (Sondenaa et al., 2013), and the studies conducted on nurses in Korea, India, Australia, and Portugal (Amin et al., 2015; Craigie et al., 2016; Duarte et al., 2016; Kim and Choi, 2012; Kim et al., 2015; Sacco et al., 2015). The differences in scores can be attributed to individual characteristics such as nurses working in different fields, being women, being single, having a short period of nursing experience, having low perceived social support, having high levels of personal distress and perceived stress, having low empathic concern, the professional values possessed, and the diversity and intensity of working conditions.

Resilience is an important weapon against compassion fatigue. A resillient nurse has some characteristics like the ability to cope, hope, control, flexibity, competence, adaptibity, self-healing and coherence (Zhang et al., 2018). If a nurse with these features can overcome compassion fatigue and the quality of life improves, turnover rates may decrease (Hart et al., 2014, Zhang et al., 2018). In this study, the total resilience scale score of the nurses is above the median and the nurses are resilient. A study on nurses working at one University 
Research and Practice Hospital (Taş, 2013) studied the factors affecting the resilience of nursing students and found that the average RSA total score was similar (Güngörmüş et al., 2015). It is pleasing that the resilience of nurses is high in both our study and other studies; because resilient nurses will experience less compassion fatigue and burnout. A study conducted on 753 Australian nurses, found that there is a relationship between professional experience, age, and resilience and that the resilience of the nurses increased with age and professional experience. In this respect, it can be suggested that one of the reasons for the high resilience scores of nurses in our study is that the average age is 39.94 and that the average years of work experience are 13 (Gillespie et al., 2009).

In this study, there is a positive moderately significant relationship between the resilience and occupational satisfaction scores and a negative moderately significant relationship between resilience and burnout. No significant relationship was established between resilience and compassion fatigue. In a study carried out on military health workers (Leners et al., 2014), there was a negative significant relationship between resilience and burnout and compassion fatigue, and a positive significant relationship between resilience and occupational satisfaction. There was a negative significant relationship between the resilience of nurses working in oncology and their burnout levels (Kutluturkan et al., 2016). On the other hand, resilience was an important variable in explaining occupational satisfaction (Hegney et al., 2015). Another study emphasized that psychological empowerment and low work stress are the most important determinants in increasing the occupational satisfaction of nurses (Larrabee et al., 2010). A study of professionals working in a trauma intervention team, found that there was a positive significant relationship between resilience and occupational satisfaction and a negative significant relationship between burnout and compassion fatigue (Burnett and Wahl, 2015). These results are similar to our study. Being resilient ensures that nurses experience less compassion fatigue and burnout while, at the same time, emerging as an important factor that increases their occupational satisfaction. In line with this information, many studies point to the importance of psychologically empowering and improving the working conditions of nurses (McCann et al., 2013; Rushton et al., 2015; Sondenaa et al., 2013).

The resilience levels of the nurses are above average, and their occupational satisfaction, burnout, and compassion fatigue scores are below average. As the resilience of the nurses increases, their occupational satisfaction also increases, and as their resilience decreases, their burnout level increases. The resilience of nurses is a factor that decreases burnout and compassion fatigue and increases occupational satisfaction. It should not be forgotten that improving the resilience of nurses will also be beneficial for the improvement of the quality of the care provided by nurses and patient satisfaction.

Compassion satisfaction, burnout and compassion fatigue is a very important component of ProQOL. High compassion and resillience may relieve compassion fatigue, burnout and turnover rates (Baek et al., 2019). The first step in lowering compassion fatigue and burnout (and thus preventing compassion fatigue) is to recognize the signs and symptoms of compassion fatigue and burnout by nurse mangers. Monitoring nurses' work environment and personal life needs to be implemented to address the build-up and continuation of compassion fatigue and burnout (Bride and Figley, 2009; Maslach et al., 2001). For this reason, in this study, the presence and level of compassion fatigue and burnout in nurses was investigated. Improving the resilience of ICU nurses should be a useful strategy for improving their mental health and occupational satisfaction. But we need programs designed to facilitate the development of resilience in all nurses working in intensive care units. With these programs, we can reduce nurses' compassion fatigue and burnout level and increase their occupational satisfaction. The care that will be provided by the ICU nurse who has high occupational satisfaction will be more qualified.

\section{Limitations}

One of the limitations of the study was that it was carried out on a limited number of nurses who worked in intensive care units and volunteered to participate. As the number of intensive care beds, nurses per patient, and patient characteristics differ across the country, working conditions in intensive care units also differ from hospital to hospital. Therefore, the results of the study can only be generalized for nurses working in the institution where the study was conducted and cannot be generalized for nurses working in other institutions.

\section{Conclusions}

The results of this study can be used in the future to plan works aimed at decreasing the burnout levels and compassion fatigue and increasing the occupational satisfaction levels of nurses by increasing their resilience levels. Nurse managers can organize programs that will improve the resilience of intensive care nurses to burnout. According to the results of our study, it would be advisable to carry out special practices aimed at improving the resilience of nurses in future works planned for decreasing their burnout levels and compassion fatigue.

\section{Conflict of interests}

The authors have no conflict of interests to report.

\section{Acknowledgements}

This research was presented in part at the 4th International and the 8th National Psychiatric Nursing Congress, Manisa, Turkey, November 06-09, 2016. We would like to thank all the nurses who participated in the study.

\section{Author's institutional affiliations}

NGB is working at the university hospital in which the study was carried.out. She is a nurse. EBY is working at the university at which the study is conducted. EEA worked at the university at which the study is conducted. EEA is currently working at University of Health Sciences.

\section{Funding}

This research did not receive a specific grant from funding agencies in the public, commercial, or non-profit sectors.

\section{Authorship}

All of the authors listed meet the authorship criteria according to the latest guidelines of the International Committee of Medical Journal Editors and are in agreement with the manuscript. EEA, EBY, NGA designed the study, EEA, NGA collected the data, EEA, EBY performed the data analysis, EEA, EBY, NGA wrote the manuscript. 


\section{Odolnost, profesní spokojenost, vyhoření a únava ze soucitu u tureckých sester na jednotkách intenzivní péče}

\section{Souhrn}

Odolnost a profesní spokojenost sester jsou důležitými faktory pro prevenci syndromu vyhoření, únavy ze soucitu a fluktuace sester na jednotkách intenzivní péče (JIP). Tato studie stanovila vztah mezi odolností a profesní spokojeností, syndromem vyhoření a únavou ze soucitu u tureckých sester na jednotkách intenzivní péče. Tato popisná korelační průřezová studie zahrnovala 79 sester z JIP. Sběr dat byl proveden pomocí formuláře pro osobní údaje, stupnice kvality života pracovníků (Life Quality Scale for Workers) a stupnice odolnosti pro dospělé (Resilience Scale for Adults). Bylo zkoumáno průměrné skóre pro dílčí skóre ProQOL; pracovní spokojenost $24,64 \pm 8,45$, vyhoření $19,17 \pm 6,24$ a únava ze soucitu $13,45 \pm 5,69$. Celkové skóre stupnice odolnosti bylo $128,67 \pm 14,84$. Mezi odolností a uspokojením z povolání je pozitivní průměrný vztah a mezi odolností a syndromem vyhoření záporný průměrný vztah. Zlepšení odolnosti sester na JIP může být užitečnou strategií pro zvýšení jejich profesní spokojenosti a snížení možnosti vyhoření. Manažeři mohou při navrhování programů výsledky této studie využít k usnadnění rozvoje odolnosti všech sester pracujících na jednotkách intenzivní péče.

Klíčová slova: odolnost; ošetřovatelství; profesní spokojenost; únava ze soucitu; vyhoření

\section{References}

1. Amin AA, Vankar JR, Nimbalkar SM, Phatak AG (2015). Perceived stress and professional quality of life in neonatal intensive care unit nurses in Gujarat, India. Indian J Pediatr 82(11): 1001-1005. DOI: 10.1007/s12098-015-1794-3.

2. Baek J, Cho H, Han K, Lee H (2019). Association between nursing work environment and compassion satisfaction among clinical nurses. J Nurs Manag 28(2): 368-376. DOI: 10.1111/ jonm.12937.

3. Basım HN, Çetin F (2011). The reliability and validity of the resilience scale for adults - Turkish version. Turkish Journal of Psychiatry 22(2): 104-114.

4. Başkale H, Partlak Günüşen N, Serçekuş P (2016). Investigation of professional quality of life and affecting factors of nurses who are working in a state hospital. Pam Med J 9(2): 125-133. DOI: $10.5505 / \mathrm{ptd} .2016 .03779$.

5. Beck CT (2011). Secondary traumatic stress in nurses: A systematic review. Arch Psychiatr Nurs 25(1): 1-10. DOI: 10.1016/j.apnu.2010.05.005.

6. Bride B, Figley CR (2009). Secondary traumatic stress. In: Fisher B, Lab S (Eds), Encyclopedia of Victimology and Crime Prevention. Thousand Oaks, CA: Sage Publications.

7. Burnett HJ, Wahl K (2015). The compassion fatigue and resilience connection: A survey of resilience, compassion fatigue, burnout, and compassion satisfaction among trauma responders. Int J Emerg Ment Health 17(1): 318-326.

8. Coşkun S, Şarlak K, Taştan H (2015). An investigation on the level of learned resourcefulness and professional quality of life of psychiatric nurses: A comparative study. Gümüşhane University Journal of Health Sciences 4(1): 84-101.

9. Craigie M, Slatyer S, Hegney D, Osseiran-Moisson R, Gentry E, Davis S, et al. (2016). A pilot evaluation of a mindful self-care and resiliency (MSCR) intervention for nurses. Mindfulness 7(3): 764-774. DOI: 10.1007/s12671-016-0516-x.

10. Duarte J, Pinto-Gouveia J, Cruz B (2016). Relationships between nurses' empathy, self-compassion and dimensions of professional quality of life: A cross-sectional study. Int J Nurs Stud 60: 1-11. DOI: 10.1016/j.ijnurstu.2016.02.015.

11. Earvolino-Ramirez M (2007). Resilience: a concept analysis. Nurs Forum 42(2): 73-82. DOI: 10.1111/j.17446198.2007.00070.x.

12. Figley CR (Ed.) (1995). Compassion fatigue: coping with secondary traumatic stress in those who treat the traumatized. New York: Brunner Mazel Inc, pp: 1-10.

13. Figley CR (2002). Compassion fatigue: psychotherapists' chronic lack of self care. J Clin Psychol 58(11): 1433-1441. DOI: $10.1002 / j c l p .10090$.
14. Gentry JE, Baranowsky AB, Dunning K. (2002). ARP: The accelerated recovery program (ARP) for compassion fatigue. In: Figley CR (Ed.) Treating compassion fatigue. New York: Routledge, pp. 123-138.

15. Gillespie BM, Chaboyer W, Wallis M (2009). The influence of personal characteristics on the resilience of operating room nurses: a predictor study. Int J Nurs Stud 46(7): 968-76. DOI: 10.1016/j.ijnurstu.2007.08.006.

16. Güngörmüş K, Okanlı A, Kocabeyoğlu T (2015). Resilience and influencing factors of nursing students. J Psy Nurs 6(1): 9-14. DOI: $10.5505 /$ phd.2015.80299.

17. Hart PL, Brannan JD, De CM (2014). Resillience in nurses: An integrative review. J Nurs Manag 22(6): 720-734. DOI: 10.1111/j.1365-2834.2012.01485.x.

18. Hegney DG, Rees CS, Eley R, Osseiran-Moisson R, Francis K (2015). The contribution of individual psychological resilience in determining the professional quality of life of Australian nurses. Front Psychol 6: 1613. DOI: 10.3389/fpsyg.2015.01613.

19. Hooper C, Craig J, Janvrin DR, Wetsel MA, Reimels E (2010). Compassion satisfaction, burnout, and compassion fatigue among emergency nurses compared with nurses in other selected inpatient specialties. J Emerg Nurs 36(5): 420-427. DOI: 10.1016/j.jen.2009.11.027.

20. Ingebretsen LP, Sagbakken M (2016). Hospice nurses' emotional challenges in their encounters with the dying. Int J Qual Stud Health Well-being 11(1): 31170. DOI: 10.3402/qhw.v11.31170.

21. Injeyan $M C$, Shuman $C$, Shugar $A$, Chitayat D, Atenafu EG, Kaiser A (2011). Personality traits associated with genetic counselor compassion fatigue: the role of dispositional optimism and locus of control. J Genet Couns 20(5): 526-540. DOI: 10.1007/s10897-011-9379-4.

22. Kim HJ, Choi HJ (2012). Emergency nurses' professional quality of life: compassion satisfaction, burnout, and secondary traumatic stress. Journal of Korean Academy of Nursing Administration, 18(3): 320-328. DOI: 10.11111/ jkana.2012.18.3.320

23. Kim K, Han Y, Kwak Y, Kim JS (2015). Professional quality of life and clinical competencies among Korean nurses. Asian Nurs Res (Korean Soc Nurs Sci) 9(3): 200-206. DOI: 10.1016/j. anr.2015.03.002.

24. Kutluturkan S, Sozeri E, Uysal N, Bay F (2016). Resilience and burnout status among nurses working in oncology. Ann Gen Psychiatry 15: 33. DOI: 10.1186/s12991-016-0121-3.

25. Larrabee JH, Wu Y, Persily CA, Simoni PS, Johnston PA, Marcischak TL, et al. (2010). Influence of stress resiliency on RN job satisfaction and intent to stay. West J Nurs Res 32(1): 81-102. DOI: 10.1177/0193945909343293.

26. Leners C, Sowers R, Quinn Griffin MT, Fitzpatrick JJ (2014). Resilience and professional quality of life among military 
healthcare providers. Issues Ment Health Nurs 35(7): 497-502. DOI: $10.3109 / 01612840.2014 .887164$.

27. Lim J, Hepworth J, Bogossian F (2011). A qualitative analysis of stress, uplifts and coping in the personal and professional lives of Singaporean nurses. J Adv Nurs 67(5): 1022-1033. DOI: 10.1111/j.1365-2648.2010.05572.x.

28. Luthans F, Avey JB, Avolio BJ, Norman SM, Combs GM (2006). Psychological capital development: Toward a microintervention. J Organizational Behav 27(3): 387-393. DOI: $10.1002 /$ job.373.

29. Maslach C, Schaufeli WB, Leiter MP (2001). Job burnout. Annu Rev Psychol 52(1): 397-422. DOI: 10.1146/annurev. psych.52.1.397.

30. McCann CM, Beddoe E, McCormick K, Huggard P, Kedge S, Adamson C, Huggart P (2013). Resilience in the health professions: A review of recent literature. International Journal of Wellbeing 3(1): 60-81. DOI: 10.5502/ijw.v3i1.4.

31. McHolm F (2006). Rx for compassion fatigue. J Christ Nurs 23(4): 12-19. DOI: 10.1097/00005217-200611000-00003.

32. Meadors P, Lamson A (2008). Compassion fatigue and secondary traumatization: provider selfcare on intensive care units for children. J Pediatr Health Care 22(1): 24-34. DOI: 10.1016/j.pedhc.2007.01.006.

33. Najjar N, Davis LW, Beck-Coon K, Doebbeling CC (2009). Compassion fatigue a review of the research to date and relevance to cancer-care providers. J Health Psychol 14(2): 267-277. DOI: 10.1177/1359105308100211.

34. Potter P, Deshields T, Berger JA, Clarke, M, Olsen S, Chen L (2013). Evaluation of a compassion fatigue resiliency program for oncology nurses. Oncol Nurs Forum 40(2): 180-7. DOI: 10.1188/13.ONF.180-187.

35. Rushton CH, Batcheller J, Schroeder K, Donohue P (2015). Burnout and resilience among nurses practicing in high-intensity settings. Am J Crit Care 24(5): 412-420. DOI: $10.4037 /$ ajcc2015291.

36. Sacco TL, Ciurzynski SM, Harvey ME, Ingersoll GL (2015). Compassion satisfaction and compassion fatigue among critical care nurses. Crit Care Nurse 35(4): 32-43. DOI: 10.4037/ ccn2015392.

37. Shen J, Yu H, Zhang Y, Jiang A (2015). Professional quality of life: A cross-sectional survey among Chinese clinical nurses. Nurs Health Sci 17(4): 507-15. DOI: 10.1111/nhs.12228.
38. Sirin M, Yurttas A (2015). Cost of nursing care: Compassion fatigue. DEUHFED 8(2): 123-130.

39. Slatten LA, Carson KD, Carson PP (2011). Compassion fatigue and burnout: What managers should know. Health Care Manag (Frederick) 30(4): 325-333. DOI: 10.1097/ HCM.0b013e31823511f7.

40. Sondenaa E, Lauvrud C, Sandvik M, Nonstad K, Whittington R (2013). Resilience and professional quality of life in staff working with people with intellectual disabilities and offending behavior in community based and institutional settings. Health Psychol Res 1(1): e3. DOI: 10.4081/hpr.2013.e3.

41. Stamm BH (2002). Measuring compassion satisfaction as well as fatigue: Developmental history of the compassion satisfaction and fatigue test. In: Figley CR (Ed.). Treating compassion fatigue. New York: Brunner-Routledge, pp: 178-208.

42. Taş S (2013). Assessment of psychological resilience, percevied stress and depression in nurses working in Düzce University Hospital. Unpublished master's thesis, Düzce University Health Sciences Institute, Department of Public Health.

43. Wee D, Myers D (2002). Compassion satisfaction, compassion fatigue, and critical incident stress management. Int J Emerg Ment Health 5(1): 33-37.

44. Wentzel D, Brysiewicz P (2014). The Consequence of caring too much: compassion fatigue and the trauma nurse. J Emerg Nurs 40(1): 95-97. DOI: 10.1016/j.jen.2013.10.009.

45. Yeșil A, Ergun Ü, Amasyalı C, Er F, Olgun NN, Aker AT (2010). Validity and reliability of the Turkish version of the professional quality of life scale. Archives of Neuropsychiatry 47(2): 111-117. DOI: 10.4274/npa.5210.

46. Yoder EA (2010). Compassion fatigue in nurses. Appl Nurs Res 23(4): 191-197. DOI: 10.1016/j.apnr.2008.09.003.

47. Young JL, Derr DM, Cicchillo VJ, Bressler S (2011). Compassion satisfaction, burnout, and secondary traumatic stress in heart and vascular nurses. Crit Care Nurs Q 34(3): 227-234. DOI: 10.1097/CNQ.0b013e31821c67d5.

48. Zhang YY, Han W, Qin W, Yin HX, Zhang CF, Kong C, Wang YL (2018). Extend of compassion satisfaction, compassion fatigue and burnout in nursing: A meta-analysis. J Nurs Manag 26(7): 810-819. DOI: 10.1111/janm.12589. 